\title{
P170: Evaluation of knowledge and practices of hospital waste management in Nigeria: implications for the control of healthcare associated infections
}

\author{
E Okechukwu $^{1 *}$, A Onyenwenyi $^{2}$ \\ From 2nd International Conference on Prevention and Infection Control (ICPIC 2013) \\ Geneva, Switzerland. 25-28 June 2013
}

\section{Objectives}

The medical waste management is a recognized public health problem, since it exposes healthcare workers, patients and the environment to infection, injury and contamination.

In the era of HIV / AIDS, hepatitis and other epidemics, local data are required to implement policies for prevention and control measures.

\section{Methods}

To assess the knowledge and practices of medical waste management (GDM) in health facilities to facilitate the design activities GDM capacity building to improve the safety of care.

\section{Results}

Internationally validated instruments were used to obtain data from 32 health facilities in four states on the development of key messages, advocacy / awareness sessions. 56 health workers and educational institutions, local authorities were concerned.

After 6 months, capacity building workshops have been made to improve the immediate impact of the project messages on the dangerous practices of GDM prevalent in $97 \%$ of schools. A self-administered post-intervention questionnaire was used to compare the pre-test scores.

\section{Conclusion}

In 28 workshops, staff and students 210016 educational institutions and health care organizations and 59 civil society have been affected by training on GDM. The post-

${ }^{1}$ Centre for Health Research \& Development, Action Family Foundation, Nigeria

Full list of author information is available at the end of the article intervention evaluation showed an improvement of $63 \%$ on the issues of knowledge and practice.

Conclusions: This study provides a framework for evidence-based integration of GDM in developing countries to prevent nosocomial infections, promote patient safety and to ensure the sustainability of the healthcare environment.

\section{Disclosure of interest}

None declared.

\section{Author details}

${ }^{1}$ Centre for Health Research \& Development, Action Family Foundation, Nigeria. ${ }^{2}$ Institute of Child Health \& Primary Care, Lagos University Teaching Hospital, Lagos, Nigeria.

Published: 20 June 2013

\section{doi:10.1186/2047-2994-2-S1-P170}

Cite this article as: Okechukwu and Onyenwenyi: P170: Evaluation of knowledge and practices of hospital waste management in Nigeria: implications for the control of healthcare associated infections. Antimicrobial Resistance and Infection Control 2013 2(Suppl 1):P170.

Submit your next manuscript to BioMed Central and take full advantage of:

- Convenient online submission

- Thorough peer review

- No space constraints or color figure charges

- Immediate publication on acceptance

- Inclusion in PubMed, CAS, Scopus and Google Scholar

- Research which is freely available for redistribution

\section{() Biomed Central}

